\title{
EWSR1/NR4A3 Fusion Protein
}

National Cancer Institute

\section{Source}

National Cancer Institute. EWSR1/NR4A3 Fusion Protein. NCI Thesaurus. Code C99254.

A fusion protein encoded by the EWSR1/NR4A3 fusion gene. This protein is comprised of the transactivation domain of the RNA-binding protein EWS followed by the entire nuclear receptor subfamily 4 group A member 3 protein. 